\title{
Pragmatics in EFL teaching: how speech acts are addressed in a Brazilian textbook series
}

Paulo Ott TAVARES ${ }^{1}$

\begin{abstract}
This paper aims at discussing and analyzing the approach to speech acts in an EFL textbook series used in Brazilian public schools. In order to do that, the concepts of pragmatics and pragmatic competence, as well as their implications to foreign language (FL) teaching, are discussed. Then, a brief review of the Speech Act Theory is presented. After describing the approach to FL teaching proposed by the PCNs and the selection of textbooks through the PNLD, we analyze one series, selected for the 2014-2016 triennium. The conclusion is that speech acts are not deeply approached, but that is in accordance with the goals of the series.
\end{abstract}

Keywords: speech acts, pragmatic competence, foreign language teaching.

\section{Introduction}

Learning a foreign ${ }^{2}$ language is much more than simply learning its vocabulary, grammar, and pronunciation; it's about learning how to use it to "achieve a communicative purpose" (Widdowson, 1978:2). When the notions of language in use or use of language are brought up, pragmatics inevitably follows.

This paper aims at discussing the relationship between pragmatics and EFL teaching in Brazil through the analysis of the presentation and addressing of speech acts in a textbook series used in Brazilian public schools. In order to do that, we will first present a brief definition of pragmatics and the concept of pragmatic competence, followed by an explanation of the Speech Act Theory as formulated by Austin (1962) and advanced by Searle (1969), and its implications to foreign language teaching. Then, the focus will shift to Brazil's policy on foreign language teaching and the National Textbook Program $\left(\mathrm{PNLD}^{3}\right)$. After that, four textbooks will be analysed in terms of the way they deal (or do not) with speech acts in English. Finally, we will discuss and comment on the results based on the previous theoretical presentation.

\subsection{Pragmatics, pragmatic competence, and language teaching}

Many authors have come with slightly different definitions of pragmatics. However, concepts such as meaning, context, use, intention, user, inference, and utterance, are invariably present in most of the definitions, depending on the intended focus of description. According to Celce-Murcia and Olshtain (2000:20),

\footnotetext{
${ }^{1}$ Graduate student in Linguistics at Pontifícia Universidade Católica do Rio Grande Sul.

2 The term foreign language is used in this paper to refer to any language other than the speaker's first language, thus including concepts such as second language and/or additional language.

${ }^{3}$ Programa Nacional do Livro Didático.
} 
pragmatics studies the context within which an interaction occurs as well as the intention of the language user. (...) Pragmatics also explores how listeners and readers can make inferences about what is said or written in order to arrive at an interpretation of the user's intended meaning. (italics added)

Hedge (2000:411) states that pragmatics is "the study of the real use of language in relation to context, language user, and topic".

It is clear from these two definitions that pragmatics involves much more than just the grammar of a language: it's when grammar is put into use in real interactions that pragmatics starts to work, which leads to the notions of linguistic competence and pragmatic competence: the former could be defined as "knowledge of the language itself, its form and meaning" (Hedge, 2000:46), while the latter is "a set of internalized rules of how to use language in socioculturally appropriate ways, taking into account the participants in a communicative interaction and features of the context within which the interaction takes place" (Celce-Murcia and Olshtain, 2000:19).

When it comes to language teaching, research has shown that "grammatical development does not guarantee a corresponding level of pragmatic development" (BardoviHarlig and Dornyei, 1998:234). Consequently, even advanced learners, with extensive knowledge of language structures, may fail to participate properly in a given communicative situation if they haven't achieved a good level of pragmatic competence. Pragmatic failures might even cause speakers to be seen as rude or impolite. Therefore, it is claimed that there should be room for a focus on pragmatics in foreign language teaching (Murray, 2010:294).

The reason we have been highlighting this distinction between grammar knowledge and pragmatic development is because there has been a history of EFL teaching focused on grammar, with no attention to context, meaning, or speaker intention. Brown (2007:24) claims that it was only in the 1970s that "research on second language learning and teaching grew from an offshoot of linguistics to a discipline in its own right". He adds that the development of the area is still in progress, as "we continue to probe the nature of social, cultural, and pragmatic features of language" (Brown, 2007:45).

As a result of this change in EFL teaching methods and approaches, there was the "development of approaches that highlighted the fundamentally communicative properties of language" (Brown, 2007:45, italics added). For this reason, it is essential to make sure that pragmatic aspects of language are included in EFL lessons, for there is no successful communicative exchange without pragmatic appropriateness.

\subsection{Speech Act Theory and language teaching}

Among the topics studied by pragmatics, one can find deixis, presupposition, implicature, and speech acts. The Speech Act Theory (SAT) was formulated by J.L. Austin and 
published in his book How to do things with words in 1962. Later, his ideas were "refined, systematized, and advanced especially by his Oxford pupil, the American philosopher John R. Searle" (Huang, 2007:93). O'Keeffe (2011:84) argues that "at the heart of SAT lies the assumption that utterances can be described in terms of the actions they perform". She gives the example of the utterances It is late or It is cold, which, depending on the context, may carry different functions: "the former may be a suggestion to leave a party while the latter may be a request to shut the window" (O'Keeffe, 2011:83).

At first, Austin worked with the notion of sentences being defined as constatives or performatives. According to O'Keeffe (2011:84), "the former could be analyzed as either being 'true' or 'false' while the latter could be described in terms of the act that they perform when uttered in a given context". Verbs like apologize, suggest, and declare could be described as explicit performatives, for they name the action which they perform.

Later, he changed the focus of his theory from the distinction between constatives and performatives to the different ways of performing speech acts, regardless of the use of a performative verb. As O'Keeffe (2011:85) states, "most utterances, regardless of whether they include a performative verb, are used to perform speech acts $^{4}$, and in doing so to convey the intention of the speaker."

Searle (1969) grouped speech acts under five categories: declaratives, representatives, expressives, directives, and comissives. O' Keeffe (2011:86) summarizes his taxonomy:

- Declaratives: speech acts that effect immediate changes in the institutional state of affairs as a result of being performed (declaring war, firing from employment, christening, etc.);

- Representatives: speech acts that commit the speaker to the truth of the expressed proposition (asserting, concluding, etc.);

- Expressives: speech acts that express a psychological state (thanking, apologizing, welcoming, congratulating, etc.);

- Directives: speech acts that are attempts by the speaker to get the addressee to do something (requesting, questioning, ordering, etc.);

- Commissives: speech acts that commit the speaker to some future course of action (promising, offering, threatening, etc.).

\footnotetext{
${ }^{4}$ According to Huang (2007:102), "the term speech act in its narrow sense is often taken to refer specifically to illocutionary acts". Illocutionary acts refer to the kind of action a speaker intends to accomplish when producing an utterance, like accusing, apologizing, ordering, refusing, etc.
} 
The connection between speech acts and language teaching can be best exemplified through what is called the Functional Syllabus, which is an approach ${ }^{5}$ to language teaching which focuses on language functions, rather than grammatical structures per se. It was developed in the 1970s as a reaction to grammar-centered approaches and it "focused strongly and in some of its interpretations, exclusively - on the pragmatic purposes to which we put language" (Brown, 2007:33). Though it has been discussed whether it developed learners' communicative competence, "by attending to the functional purposes of language, and by providing contextual (notional) settings for the realization of those purposes" (Brown, 2007:34), it was important to set the stage for future changes regarding the teaching of foreign languages.

Although many EFL courses and materials do not describe themselves as functional, the idea of language functions is often present in textbooks. A quick look at the table of contents of textbooks might find items such as making suggestions, requests, giving instructions, etc. The question is: how are these functions (speech acts) approached? Bardovi-Harlig (2001:25), describing the approach to speech acts in textbooks ${ }^{6}$, states that "it is often the case that a particular speech act or language function is not represented at all. In other cases, speech acts are represented, but not realistically". However, Kasper and Rose (2001:3) point out that "curricula and materials developed in recent years include strong pragmatic components or even adopt a pragmatic approach as their organizing principle".

\section{EFL in Brazil: a case study of a textbook series}

According to $\mathrm{PCNs}^{7}$ (Brasil, 1998:37), the study of a foreign language is mandatory in Brazilian schools from the $6^{\text {th }}$ grade onwards. Though the official guidelines state that the focus should be on reading skills, it also mentions speaking, listening, and writing. The sociointeractional aspect of language use is highlighted, and language is defined as a social practice. The document states that "the repetitive study of words and structures will only result in making learners disinterested in the target language, especially because they might see no point in studying it, unless they have the opportunity to risk using its communicative functions" ${ }^{\text {"8 }}$ (Brasil, 1998:54, italics added).

\footnotetext{
${ }^{5}$ This paper will not deal with the discussion of methods and approaches, their different definitions, similarities and contrasts. For this discussion, see Brown, 2007.

${ }^{6}$ The author analyzed textbooks used in ESL contexts.

${ }^{7}$ PCN stands for Parâmetros Curriculares Nacionais (National Curricular Parameters). Established by the Brazilian government in 1996, they are guidelines to organize school curricula throughout the country.

${ }^{8}$ In Portuguese: "o estudo repetitivo de palavras e estruturas apenas resultará no desinteresse do aluno em relação à língua, principalmente porque, sem a oportunidade de arriscar-se a interpretá-la e a utilizá-la em BELT Journal • Porto Alegre • v.5 • n.1 • p. 30-39 • janeiro/junho 2014 
It can be concluded from what has been exposed that, at least in terms of the government's guidelines, there is a focus on language as communication, which implicates that pragmatics should be involved in foreign language teaching to some degree.

The Brazilian government runs a program called PNLD ${ }^{9}$ (National Textbook Program), which provides public schools with textbooks for learners. The program works as follows: the government issues guidelines with the criteria for textbooks to participate in the program. Then, publishers submit their books, which are assessed by a body of professionals designated by the Ministry of Education. Samples of the approved textbooks are sent to schools, which can choose the series they consider that best suits their needs. The following year, schools receive the books, which are used for three years, when a new process of selection begins.

We are now going to look into one textbook series selected in 2013 and that is going to be used until 2016 in some Brazilian public schools. Due to time and (especially) space constraints, only one of the three approved series was chosen. The aim of the investigation is to see if speech acts are presented along the series and, if they are, how they are approached.

\subsection{Description of the series and analysis}

The series is called It Fits, and it is composed of four volumes (from $6^{\text {th }}$ to $9^{\text {th }}$ grade), each made of a student's book and a teacher's book, both with an audio CD featuring listening activities. Each volume has eight units, which deal with a specific topic (e.g. the internet and me, technology, changes, famous people, etc.) from which the language work is based on. Each unit has the following sections:

- $\quad$ Reading (Reading Corner)

- Vocabulary (Words, words, words)

- Grammar (Grammar bits)

- Writing (Pen to paper)

- Speaking (Speaker's corner)

- Listening (Open your ears)

At the end of the book, there are four extra sections: Self Assessment, Grammar Reference, Glossary, and Ideas for Reading/Useful Links.

The teacher's manual deals with the objectives and the approach to language teaching and learning adopted in the series. The practice of the four skills (speaking, listening, reading and writing) is encouraged (Chequi, 2012:5), though there seems to be a stronger focus on

suas funções de comunicação, acabará não vendo sentido em aprendê-la”. This, and the other translations in this paper, have been done by the author.

${ }^{9}$ In Portuguese: Programa Nacional do Livro Didático. 
reading and writing. When discussing the approach to language teaching and learning, it can be found that "the lack of speaking 'models' is a way to avoid presenting closed expressions for learners to repeat, most of the times, in a mechanic and decontextualized manner" and that learners should "always take into account the context in which the addressee is immersed" (Chequi, 2012:8, italics added). That shows that the series is framed under a theoretical background which views language as social, interactive, and context-dependent.

Though the authors of the series do not describe it as an especially pragmaticallyoriented collection, the next section of this paper will try to find out if the topic is discussed, since the concepts of interaction and context are considered as important in language teaching and learning. Specifically, we will try to find how speech acts are approached in the series, especially in the speaking activities.

The analysis starts with a look at the table of contents, to see if there are any speech acts presented. Then, it goes on page by page, searching for the teaching (or lack of) of speech acts.

\subsection{Volume $1\left(6^{\text {th }}\right.$ grade $)$}

The table of contents of this volume presents the speech act of introducing yourself in the speaking section of unit 8 . In the activity, which deals with online video chats, learners are asked to organize a text to introduce themselves as if they were participating in a chat. They can choose the information they want to include in their introduction, as well as the language needed to do so. At the end of the activity, they can act out their texts.

In the first unit, which is about identity, there's a remark on the appropriateness of some ways of greeting and introducing yourself. Though the topic is not explored in detail, there's an interesting comment:

In English, like in Portuguese, you can use different greeting to introduce yourself. For example: Hi, my name's.../ Hello, I'm.../ Hi there. That depends on your preference, where you are and, sometimes, who you are talking to. Would you consider appropriate to greet the mayor of your city by saying "E aí, tudo bem?"10. That's the same in English. If you greeted someone, in a formal situation, saying Hey, what's up?, what do you think people would think of you? ${ }^{11}$ (pg.15)

It is interesting that such awareness raising be dealt with in the first unit of the first volume of the series.

\footnotetext{
${ }^{10}$ Brazilian Portuguese translation of What's up?

${ }^{11}$ In Portuguese: "Em inglês, assim como em português, você pode usar saudações diferentes ao se apresentar. Por exemplo: Hi, my name's.../ Hello, I'm.../ Hi there. Isso varia de acordo com sua preferência, o lugar e, em alguns casos, dependendo da pessoa com quem você está falando. Você acharia apropriado cumprimentar a prefeita ou o prefeito de sua cidade dizendo "E aí, tudo bem?". Do mesmo modo em inglês, se você cumprimentasse alguém, numa situação formal, dizendo Hey, what's up?, o que poderiam pensar de você?"
} 
The next occurrence of a speech act is in Unit 5, which deals with the grammar topic of the imperative. The explanation says that "when we ask someone to do or stop doing something, we can use the imperative"12 (pg.78). It also says that by using it you can suggest that something be done. It could be argued that there are other (possibly more appropriate) expressions to make suggestions, but the topic is not explored further. In the teacher's notes the author says that that is just an introduction to the topic, which is to be developed in the next unit.

The next unit keeps exploring the topic of the imperative, now pointing out that it is used to give instructions and to give orders. At the end of the book, in the grammar reference section, there's an interesting comment on the use of the imperative:

Remember to be careful with the imperative. It is used to give directions (Don't enter there. It's dangerous), in manuals, in rules. We have to avoid sentences such as Give me an ice cream. In this case, we should say Can I have an ice cream? (pg.129)

Despite pointing out to the different meanings the imperative can evoke, the use of the chunk Can I have... to ask for something is not developed any further.

\subsection{Volume $2\left(7^{\text {th }}\right.$ grade $)$}

The second volume of the series presents the speech act of giving directions in the table of contents, in the speaking section of unit 4 . The activity involves drawing a map of the area around the school, and learners are asked to choose a place which a classmate has to find on the map by asking for directions. There is a box with expressions used in that kind of interaction, like Excuse me, how do I get to...?/It's on your right./ Go straight ahead./ Take the first.../ take the bus/ etc. The teacher's notes encourage teachers to discuss the topic of asking/giving directions with learners, so as to help contextualize the language they are using.

There's one more moment when speech acts are approached: learners are asked to analyze a conversation featuring a man who is showing his house to a prospective buyer. After checking which sentences were said by the owner and which by the client, learners have to classify some expressions as greetings, small talk, or saying goodbye (leave-taking), and then they have to act out a conversation using those sentences. Figure 1 illustrates that activity.

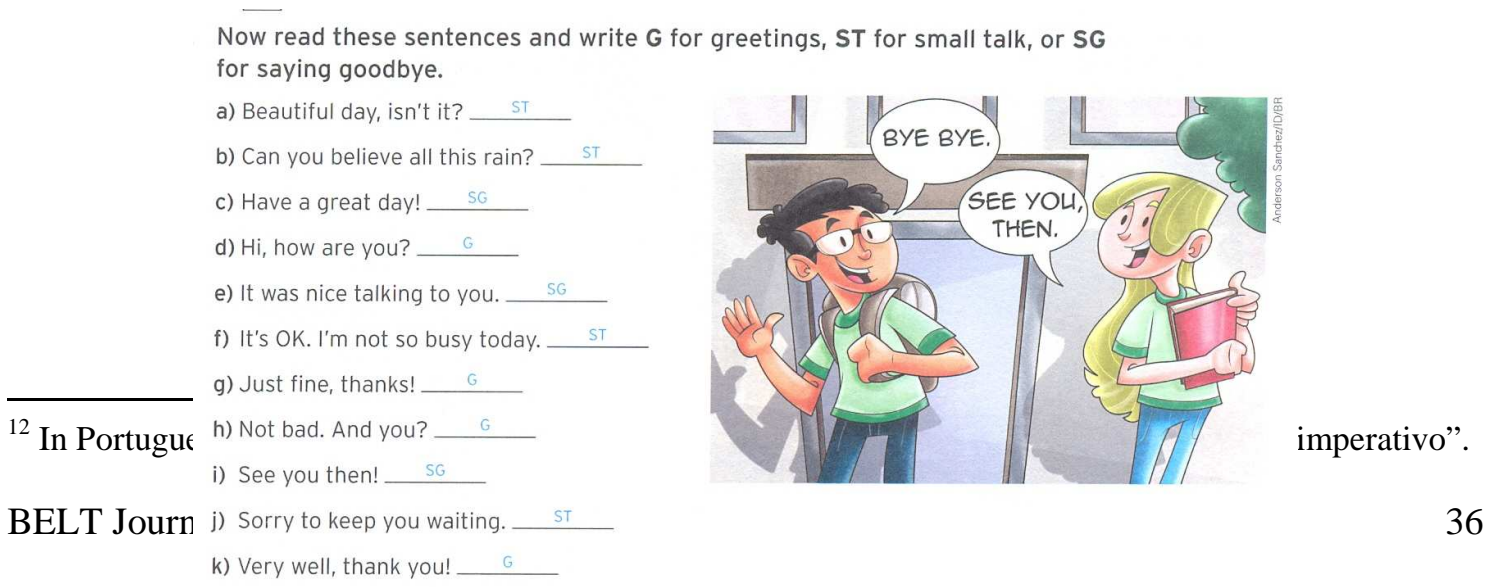


Figure 1: Extracted from It Fits, $7^{\text {th }}$ grade $(2012$, p.51)

In unit 5, speech acts are approached one more time in the speaking section. Before engaging in a role-play, learners are asked to do a matching exercise, linking speech acts such as saying hi / saying hi back / giving suggestions / accepting a suggestion / concluding, to chunks like Hey! How are things? / I'm Ok. / Not bad. / Why don't you...? / That's a great idea. / Good talking to you. / etc. Figure 2 is an image of that activity.

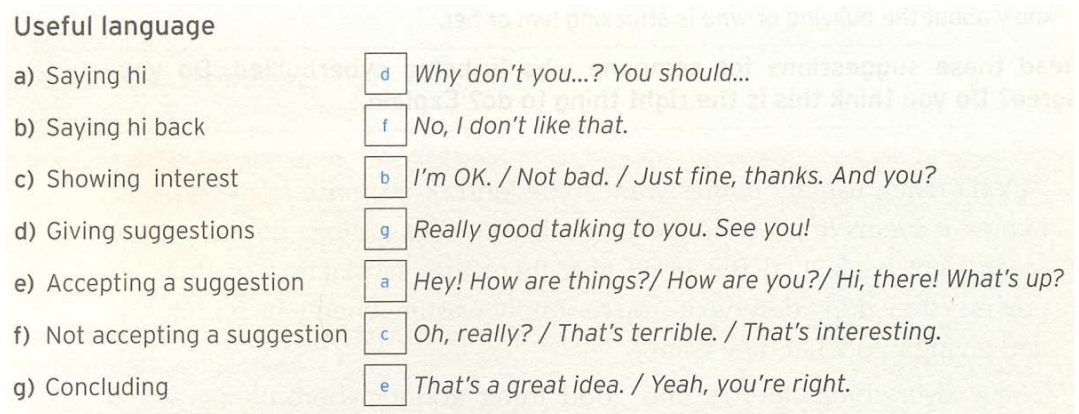

Figure 2: Extracted from It Fits, $7^{\text {th }}$ grade $(2012$, p.82)

\subsection{Volume $3\left(8^{\text {th }}\right.$ grade $)$}

The third volume features the speech acts of giving advice and giving instructions in the table of contents. The first one is dealt in unit 5 , when the topic is health and healthy eating, and the modal verb should is introduced. The lesson states that should can be used for giving advice. An interesting remark is made about a piece of advice being polite or impolite, depending on whether the modal verb is used. Learners are asked to compare a sentence with should and another one without should, choosing the one they consider more impolite or "bossy". At the end of the book, in the grammar reference section for this unit, it is mentioned that ought to and had better can also be used to give advice, but the distinctions between these forms are not addressed.

Unit 6 is about technology, and there's an activity about giving instructions. Learners are asked to prepare a conversation and act it out in class. The conversation should involve someone who bought an electronic product and has questions about it and someone who can answer those questions. Before writing down the conversation, learners can classify some sentences according to who would be likely to say them, namely, someone who doesn't know how to do something, or someone who knows how to do something. Expressions such as Do you need any help? / Let me take a look. / Sorry to bother you... / Can you help me... / etc. are present in the activity. 


\subsection{Volume $4\left(9^{\text {th }}\right.$ grade $)$}

The last volume of the series approaches speech acts in unit 1, when the speaking section is about making presentations, and unit 5 , when the writing activity is about informal emails. In unit 1, after discussing the topic of presentations, learners are asked to prepare an oral presentation and, in order to do that, they can choose from a series of chunks for introductions, changing topics, and concluding. Figure 3 illustrates that.

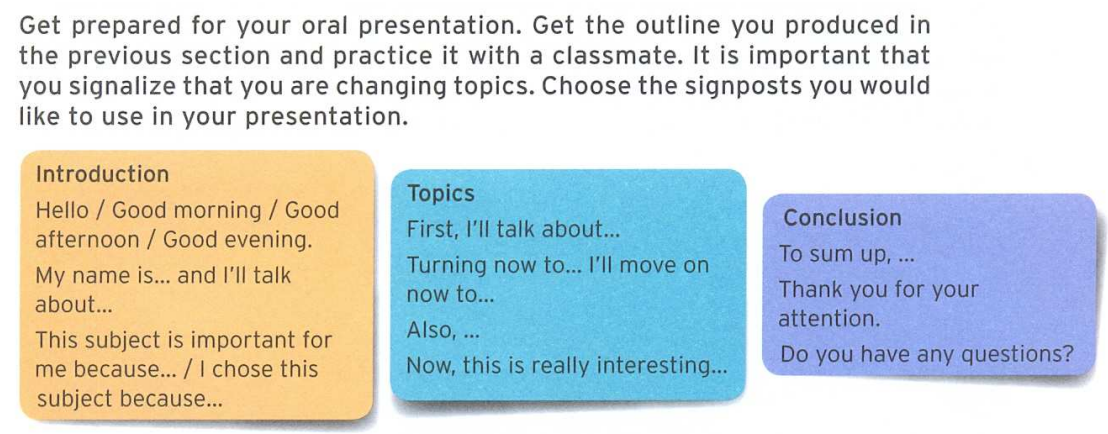

Figure 3: Extracted from It Fits, $9^{\text {th }}$ grade (2012, p.24)

Unit 5 features a writing activity in which learners have to write an informal e-mail to a friend. Before the writing, there is a discussion of appropriate openings, greetings, and closings, depending on the level of formality involved.

This volume also shows a review of modal verbs, and the notions of suggestions and advice are linked to the modal should. However, the use of will to make promises is not mentioned, just its use to talk about future events.

\section{Final remarks}

The aim of this article was to discuss the importance of developing learners' pragmatic competence in EFL classes, and a textbook series was analyzed in order to look for features of pragmatic instruction along activities, especially the presentation and practice of different speech acts. What has been found, in this case, is that, although the series is not pragmaticallyoriented, there is a good deal of pragmatic instruction throughout the collection. It could be argued that sometimes the speech acts presented were an offshoot of grammar structures, but the speech acts were the nonetheless.

Basic speech acts such as thanking and apologizing were not explicitly addressed, which could seem odd, since they are very common in everyday use of the language. Obviously, expressions like sorry and thanks were present, but other ways of performing such acts were not. Again, that could be explained by the fact that that was never the main goal of the series. 
At some moments, it seemed that opportunities to further explain the uses of certain expressions were missed, like in the case of will, linked to describing future actions, but not promises. Since it appeared amongst other modal verbs and the speech acts they perform, its use to make promises could be presented.

Overall, the results, in terms of the objective of this paper, are positive. Though the pragmatic features of the language are not explicit considered as the main drive behind the activities, some work on speech acts are present, which can be a sign that EFL teaching materials keep moving away from a focus on grammar to a focus on language in use.

\section{References}

BARDOVI-HARLIG, K.; DORNYEI, Z. Do language learners recognize pragmatic violations? Pragmatic vs. grammatical awareness in instructed L2 learning. TESOL Quarterly, 32, 233-259. 1998

BARDOVI-HARLIG. Empirical evidence of the need for instruction in pragmatics. In: ROSE, K.R.; KASPER, G. Pragmatics in language teaching (13-32). Cambridge: Cambridge University Press, 2001.

BRASIL, Secretaria de Educação Fundamental. Parâmetros curriculares nacionais : terceiro e quarto ciclos do ensino fundamental: língua estrangeira. Brasília: MEC, 1998.

BROWN, H.D. Teaching by principles: an interactive approach to language pedagogy. New York: Longman, 2007.

CELCE-MURCIA, M.; OLSHTAIN, E. Discourse and context in language teaching. Cambridge: Cambridge University Press, 2000.

CHEQUI, W. (org.) It fits $6^{\circ}, 7^{o}, 8^{\circ}, 9^{\circ}$ ano. São Paulo: SM, 2012.

HEDGE, T. Teaching and learning in the language classroom. Oxford: Oxford University Press, 2000.

HUANG, Y. Pragmatics. Oxford: Oxford University Press, 2007.

MURRAY, N. Pragmatics, awareness raising, and the Cooperative Principle. ELT Journal 64/3. 2010

O'KEEFFE, A.; CLANCY, B.; ADOLPHS, S. Introducing pragmatics in use. London: Routledge, 2011.

ROSE, K.R.; KASPER, G. Pragmatics in language teaching. Cambridge: Cambridge University Press, 2001

WIDDOWSON, H.G. Teaching language as communication. Oxford: Oxford University Press, 1978. 